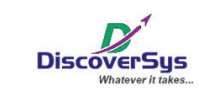

Published by DiscoverSys

\section{The role of information sources and characteristics of children in the acceptance of Japanese encephalitis (JE) mass immunization in Bali Province}

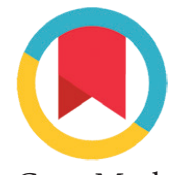

CrossMark
Nyoman Suardani, ${ }^{1 *}$ Dewa Nyoman Wirawan, ${ }^{2}$ Anak Agung Sagung Sawitri ${ }^{2}$

\section{ABSTRACT}

Background and purpose: Japanese encephalitis (JE) is a public health issue that can be prevented by immunization programs. Indonesia began the JE immunization campaign in Bali through simultaneous immunization for children aged 9 months to 15 years. Although information dissemination has been carried out, knowledge, perceptions and characteristics of mother and child can influence the acceptance and uptake of immunization for children. This study aims to determine the factors that influence acceptance of JE mass immunization in Bali Province.

Methods: Secondary data analysis was performed on the results of the JE Supplementary Immunization Activities (SIA) Udayana University survey which consisted of 1,284 mothers and 2,107 children. The survey was conducted from June-August 2018 in nine districts/cities in Bali Province. The association between knowledge, perception and respondents' characteristics with acceptance of JE mass immunization was analyzed with chi square test and multivariate analysis was conducted using logistic regression.

Results: The proportion of children who received immunization was 93.9\% (95\%Cl: 92.8-94.9). The results of the bivariate analysis showed that there was a significant association between acceptance of JE mass immunization with the child's age, sex, educational status, complete basic immunization history, mother's perception of severity, benefits, barriers, knowledge and sources of information $(p<0.05)$. Multivariate analysis shows that the variables which significantly increase JE mass immunization acceptance are information from a combination of media and face to face education ( $A O R=3.95 ; 95 \% \mathrm{Cl}: 2.01-7.77)$, schooling children ( $A O R=2.43$; 95\%Cl: 1.23-4.79), living outside of Denpasar City (AOR=2.32; 95\%Cl: 1.49-3.62), children who have received complete basic immunization ( $A O R=2.22 ; 95 \% C l: 1.42-3.49$ ), face to face information only ( $A O R=2.11$; 95\%Cl: 1.21-3.70) and girls (AOR=1.68;95\%Cl: 1.15-2.46).

Conclusion: Information disseminated via a combination of media and face to face is the strongest variable influencing JE mass immunization acceptance. Providing appropriate information through a combination of media and face to face education by health or non-health workers needs to be considered.
'Buleleng District Health Office, ${ }^{2}$ Department of Public Health and Preventive Medicine, Faculty of Medicine, Udayana University

${ }^{*}$ Correspondence to:

Nyoman Suardani, Buleleng District Health Office,

nyoman.suardani@yahoo.com
Keywords: Catch-up campaign, immunization campaign, Japanese encephalitis

Cite This Article: Suardani, N., Wirawan, D.N., Sawitri, A.A.S. 2019. The role of information sources and characteristics of children in the acceptance of Japanese encephalitis (JE) mass immunization in Bali Province. Public Health and Preventive Medicine Archive 7(2): 75-84. D01:10.15562/phpma. v7i2.210

\section{INTRODUCTION}

Japanese encephalitis (JE) is a disease caused by the JE Virus (JEV). Transmission is predominately through Culex tritaeniorhynchus as the vectors which usually lay their eggs in tepid paddy and pond water. ${ }^{1}$ Swine are the main amplifying hosts for JE and are very efficient at transmitting JEV. ${ }^{2}$

Globally more than 3 billion people are at risk for JEV infection. JEV is reported as a major cause of encephalitis in many Asian countries with an estimated 68,000 clinical cases annually. ${ }^{3}$ Countries endemic for JE in Asia include Korea, Japan, China, South Asia, Southeast Asia and Australia. ${ }^{3}$ Most JEV infections are asymptomatic, with mild symptoms of fever and headache or no obvious symptoms. ${ }^{1}$ One in 250 infections are estimated to cause severe clinical symptoms that include high fever, headache, seizures, neck stiffness, disorientation, coma, paralysis and death. ${ }^{3}$ Case fatality rate (CFR) is reported to vary between $16-30 \%$, where $30-70 \%$ of those living experience severe sequelae including paralysis and mental retardation. ${ }^{1}$ Treatment for JE is currently not available and methods of control with non-vaccine intervention are also less effective. ${ }^{4}$ Currently, immunization is the most cost effective way to prevent the occurrence of JE in humans. ${ }^{1,4-7}$

In Indonesia, there are several provinces that are high risk for JE including Bali, West Kalimantan, North Sulawesi, East Nusa Tenggara, Jakarta, Yogyakarta, Central Java, West Nusa Tenggara and Riau Islands. ${ }^{1}$ JE incidence in these areas was previously unknown as there was no adequate surveillance system. ${ }^{2}$

A hospital-based surveillance was conducted in 2001-2003 in Bali Province and it was found that JE cases were spread throughout the districts with an average incidence of 7.1 and adjusted incidence rate of 8.2 per 100,000 children aged $<10$ years. CFR 
in the study was reported at $10 \%$ and $37 \%$ experienced neurological sequelae. ${ }^{2}$ In 2014 a surveillance of acute encephalitis syndrome (AES) was carried out in 11 provinces including Bali. The results show that JE cases tend to increase every year. The highest number was in 2016 (2014-2016) where 43 out of 326 cases of AES were declared as confirmed JE cases and as many as $85 \%$ of cases were aged $\leq 15$ years. Most cases (17 cases or $39.5 \%$ ) were reported from the Province of Bali.

Several countries in Asia have implemented JE immunization programs, including Japan, Laos, China, Thailand and several other countries, and the incidence of JE has been reported to decrease dramatically in these countries after JE vaccination was implemented into routine immunization programs. ${ }^{8}$

Indonesia began initiating JE immunization in Bali Province (as a pilot project) in 2018, beginning with a JE immunization campaign in the form of simultaneous immunization in children aged 9 months to less than 15 years to reduce the incidence of JE. ${ }^{1}$ Subsequent vaccines are given to infants aged 10 months as a routine immunization. ${ }^{1}$ Immunization campaigns in Bali were conducted in all districts in March and April 2018 in schools (kindergarten, elementary, junior high) and public health centres (PHC), started with intensive preliminary information activities in schools and non-schools settings. After Bali Province, this program will be expanded in several other endemic areas in Indonesia.

In a pilot project in the Province of Bali, an evaluation of immunization coverage was carried out by Udayana University in collaboration with World Health Organization (WHO) in the form of a Japanese Encephalitis Supplementary Immunization Activities (JE SIA) survey. The survey found that the coverage of JE immunization in the campaign period was $94.45 \%$ (95\%CI: 93.67 95.22). This figure varies in each district between 88.66-98.78\% ${ }^{10}$ There were 5.55\% (95\%CI: 4.77 6.33) of children in Bali Province who did not receive JE immunization during the immunization campaign period.

JE immunization does not form herd immunity in the population..$^{4,5,11,12}$ Children who are not immunized and live in JE endemic areas, continue to have a risk of JE infection even though as many as 95\% of children already have immunity against JE, hence for immunization programs to be effective they must achieve high and continuous coverage.

Determinants of non-JE vaccination acceptance have been widely published. ${ }^{13-17}$ A study with an immunization campaign setting was conducted in Sukoharjo for the MR vaccine but only in primary school children in one village, while other studies were not conducted in an immunization campaign setting and the subjects were not aged 9 months to 15 years. The 2013 Indonesian Basic Health Research (Riskesdas) does not provide data on perceptions of mothers. Several studies have shown inconsistent results regarding the variables of mother's perception, knowledge, education level, socioeconomic status, parental occupation and age of the child. The role of mothers in child immunization is found to be important in several studies. ${ }^{18-20}$ Thus there is a knowledge gap in understanding mothers' perceptions, characteristics of mothers and children towards immunization for children aged 9 months to less than 15 years in a catch-up campaign especially for JE vaccine.

This study aims to determine the association between information sources, characteristics of mother and child and maternal perceptions of receiving JE mass immunization in children aged 9 months to 15 years in Bali Province.

\section{METHODS}

This study is a secondary data analysis of the 2018 JE SIA Udayana University Survey. The survey was conducted over June-August 2018 in nine districts/ cities in Bali Province. ${ }^{10}$

The unit of analysis for receiving immunization is the child, while the mother is the unit of analysis for socio-demographic characteristics, perceptions, knowledge and sources of information. The number of respondents in the JE SIA survey was 2,075 consisting of mothers (1,286), fathers (593), grandparents (112) and other family members (84). In our study, only mothers were selected, and from 1,286 respondents two data were incomplete, bringing the total to 1,284 . The number of children in the JE SIA survey was 3,331, and because in this study only mothers were selected as respondents, the number of children analyzed was only 2,107 out of 1,284 maternal respondents (Figure 1).

The number of mothers in the bivariate and multivariate analysis is equated with the number of children, where mothers' characteristics, knowledge and perceptions are asked once and assumed to represent all children owned regardless of their immunization acceptance status. There are 640 mothers whose data is duplicated because they have more than one child, so the mother's data matches the number of children's data, that is, 2,107. This was done to avoid difficulties in choosing children who should be excluded from the analysis, because for one maternal respondent there were children who received immunizations and some who did not. Details about the number of samples, method of sample selection and measurement tools used in the JE SIA survey have been described in 
the Coverage Evaluation of Japanese Encephalitis Supplementary Immunization Activities (JE SIA) report in Bali.

Health Belief Model (HBM) was used as the framework in the JE SIA survey to understand the perceptions of the respondents. Mothers' perceptions was measured with 10 questions. Perception of susceptibility is measured by three questions (risk of infection, risk of infection if there are pig pens and mosquito bites), perception of severity with three questions (risk of disability, death, incurability), perception of benefits with two questions about the benefits of immunization and perception of barriers with two questions (adverse event following immunization and trust in officers). Each question consists of four multiple choice answers namely "very sure", "sure", "less sure" and "not sure". The answer for "very sure" are given a score of four, "sure" are given a score of three, "less sure" are given a score of two and "not sure" are given a score of one. The score of each question is added per section, so that each section obtains a total score, namely the total score of perception of susceptibility, total score of perception of severity, total score of perception of benefits and total score of perception of barriers. The total scores for perception of susceptibility, severity, benefits and barriers are grouped into two, namely "high" and "low" with mean value of the total score for each section as the cut-off point.

Maternal knowledge is measured by 10 statements covering the mode of transmission of JE, risk of infection, susceptible age and JE immunization. Mothers who answer correctly are given a score of one and if answer incorrectly given a score of zero. The scores of each statement are added together, so the total knowledge score of the mother is obtained. The total knowledge score is further grouped into three namely "good", "fair" and "low" with the cut-off point mean value of the total score.

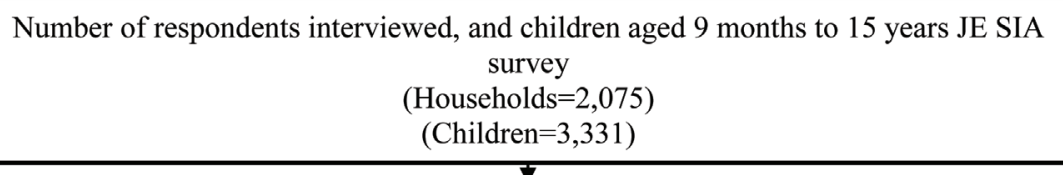

Excluded because interview not conducted with the mother (789) \& incomplete data (2)

(Households $=791$ )

(Children=1,224)

The number of mothers who have children aged 9 months to 15 years

(Mothers $=1,284$ )

(Children=2,107)

\section{Number of cases in the analysis}

$(2,107)$
The JE SIA survey provides residential area data in the form of districts/cities. In our analysis, the districts/cities are grouped into two categories based on the proportion of migrants according to the data at Bali Province Statistics Office. ${ }^{21}$ "Category 1" is Denpasar City with the proportion of migrant population $>50 \%$ and "category 2 " is 8 other districts with the proportion of migrant population $<50 \%$.

Bivariate analysis using a chi-square test was performed to determine the association between knowledge, perceptions and characteristics with the receipt of JE mass immunization. Variables whose chi-square test results have $\mathrm{p}<0.025$ were then entered into the multivariate analysis model using logistic regression with the enter method to obtain an adjusted odd ratio. This study has been approved by the Ethics Committee of the Faculty of Medicine, Udayana University/Sanglah General Hospital on March 12, 2019.

\section{RESULTS}

Table 1 indicates that most respondents graduated from high school, worked as housewives, were aged 35 to 44 years, had children who were less than or equal to two people and lived in the City of Denpasar area. The most common source of information received by mothers is from the face to face only category, followed by a combination of media dissemination and face to face.

Table 2 presents data on the characteristics of children, where the majority of children are over five years old, are male, have a school status and have complete basic immunization status.

Table 3 presents the mean scores of maternal perception and knowledge. The majority of mothers have high susceptibility perceptions, high severity perceptions, high benefit perceptions, low barrier perceptions and medium knowledge.

Table 4 shows that the variables significantly related to the acceptance of JE mass immunization are area of residence, age, sex, educational status and immunization history of the child, perception of severity, benefit, barriers, maternal knowledge and sources of information $(\mathrm{p}<0.05)$.

Table 5 presents the AOR values of the independent variables on the acceptance of JE mass immunization. Variables that are significantly increase the acceptance of JE mass immunization are information with a combination of public media dissemination and face to face $(\mathrm{AOR}=3.95$; 95\%CI: 2.01-7.77), children with school status ( $\mathrm{AOR}=2.43$; 95\%CI: 1.23-4.79), living outside Denpasar City (AOR=2.32; 95\%CI: 1.49-3.62), children who have received complete basic immunization $(\mathrm{AOR}=2.22 ; 95 \% \mathrm{CI}: 1.42-3.49)$, face to face

Figure 1 Unit of analysis selection flow 
Table 1 Characteristics of mothers

\begin{tabular}{|c|c|c|c|}
\hline Characteristic & & n $(1,284)$ & $\%$ \\
\hline \multirow[t]{5}{*}{ Level of education } & No school & 41 & 3.2 \\
\hline & Elementary & 326 & 25.4 \\
\hline & Junior high & 286 & 22.2 \\
\hline & Senior high & 449 & 35.0 \\
\hline & College/university & 182 & 14.2 \\
\hline \multirow[t]{9}{*}{ Type of employment } & Housewife & 509 & 39.6 \\
\hline & Farmer & 188 & 14.7 \\
\hline & Merchant & 108 & 8.4 \\
\hline & Laborer & 51 & 4.0 \\
\hline & Entrepreneur & 185 & 14.4 \\
\hline & Private employee & 163 & 12.7 \\
\hline & Government employee & 24 & 1.9 \\
\hline & Teacher & 23 & 1.8 \\
\hline & Other & 32 & 2.5 \\
\hline \multirow[t]{6}{*}{ Age (years) } & Median (min-max) & $36(17-62)$ & \\
\hline & $15-24$ & 86 & 6.7 \\
\hline & $25-34$ & 472 & 36.9 \\
\hline & $35-44$ & 538 & 42.1 \\
\hline & $45-54$ & 175 & 13.7 \\
\hline & $55-64$ & 8 & 0.6 \\
\hline \multirow[t]{9}{*}{ District of residence } & Klungkung & 71 & 5.5 \\
\hline & Bangli & 109 & 8.5 \\
\hline & Tabanan & 143 & 11.1 \\
\hline & Badung & 183 & 14.3 \\
\hline & Gianyar & 135 & 10.5 \\
\hline & Karangasem & 104 & 8.1 \\
\hline & Buleleng & 226 & 17.6 \\
\hline & Denpasar & 234 & 18.2 \\
\hline & Jembrana & 79 & 6.2 \\
\hline \multirow[t]{4}{*}{ Information source } & Combination of media \& face to face & 388 & 30.2 \\
\hline & Face to face only & 559 & 43.6 \\
\hline & Media only & 212 & 16.5 \\
\hline & Not informed & 125 & 9.7 \\
\hline
\end{tabular}

Table 2 Characteristics of children

\begin{tabular}{llcc}
\hline Characteristic & & $\mathbf{n ~ ( 2 , 1 0 7 )}$ & \% \\
\hline Age (years) & $\leq 5$ & 788 & 37.4 \\
\multirow{3}{*}{ Sex } & $>5$ & 1,318 & 64.6 \\
\multirow{2}{*}{ Education } & Male & 1,068 & 50.7 \\
& Female & 1,039 & 49.3 \\
Immunization & School & 1,510 & 71.7 \\
& No School & 597 & 28.3 \\
& Complete & 1,817 & 86.2 \\
& Incomplete & 290 & 13.8 \\
\hline
\end{tabular}


Table 3 Mean perception score and mother's knowledge

\begin{tabular}{llcc}
\hline Variable & & $\mathbf{n} \mathbf{( 1 , 2 8 4 )}$ & \% \\
\hline Perception of susceptibility & Mean score (min-max) & $7.04(3-11)$ & 69.1 \\
& $\geq 7$ & 887 & 30.9 \\
Perception of severity & $<7$ & 397 & 63.0 \\
& Mean score (min-max) & $7.35(3-12)$ & 37.0 \\
& $\geq 7$ & 809 & 87.8 \\
Perception of benefits & $<7$ & 475 & 12.2 \\
& Mean score (min-max) & $6.02(2-8)$ & \\
Perception of barriers & $\geq 6$ & 1,126 & 79.9 \\
& $<6$ & 157 & 20.1 \\
Knowledge & Mean score (min-max) & $5.43(2-8)$ & 1,026 \\
& $\geq 5$ & 258 & 14.7 \\
& $<5$ & $5.77(2-10)$ & 81.3 \\
& Mean score (min-max) & 189 & 4.0 \\
\hline
\end{tabular}

Table 4 Acceptance of JE mass immunization by mother's characteristics, child's characteristics, mother's perception and sources of information

\begin{tabular}{|c|c|c|c|}
\hline \multirow[b]{2}{*}{ Variable } & \multicolumn{2}{|c|}{ Acceptance of JE immunization } & \multirow[b]{2}{*}{$\mathbf{p}$} \\
\hline & $\begin{array}{c}\text { Received } \\
\text { n (\%) }\end{array}$ & $\begin{array}{c}\text { Not received } \\
\text { n (\%) }\end{array}$ & \\
\hline \multicolumn{4}{|l|}{ Mother's level of education } \\
\hline No school & $63(90.0)$ & $7(10.0)$ & \multirow{4}{*}{0.11} \\
\hline Elementary and junior high & $946(95.1)$ & $49(4.9)$ & \\
\hline Senior high & $701(94.1)$ & $44(5.9)$ & \\
\hline College or university & $268(90.2)$ & $29(9.8)$ & \\
\hline \multicolumn{4}{|l|}{ Mother's employment } \\
\hline Employed & $1,172(94.0)$ & $75(6.0)$ & \multirow{2}{*}{0.80} \\
\hline Unemployed & $805(93.7)$ & $54(6.3)$ & \\
\hline \multicolumn{4}{|l|}{ District of residence } \\
\hline Denpasar city & $360(90.0)$ & $40(10.0)$ & \multirow{2}{*}{$<0.01$} \\
\hline Other district & $1,618(94.8)$ & $89(5.2)$ & \\
\hline \multicolumn{4}{|l|}{ Age of child (years) } \\
\hline$\leq 5$ & $718(91.1)$ & $70(8.9)$ & \multirow{2}{*}{$<0.01$} \\
\hline$>5$ & $1,259(95.5)$ & $59(4.5)$ & \\
\hline \multicolumn{4}{|l|}{ Sex of child } \\
\hline Male & $986(92.3)$ & $82(7.7)$ & \multirow{2}{*}{$<0.01$} \\
\hline Female & $992(95.5)$ & $47(4.5)$ & \\
\hline \multicolumn{4}{|l|}{ Education status of child } \\
\hline No school & $535(89.6)$ & $62(10.4)$ & \multirow{2}{*}{$<0.01$} \\
\hline School & $1,443(95.6)$ & $67(4.4)$ & \\
\hline \multicolumn{4}{|l|}{ Child immunization history } \\
\hline Incomplete & $258(89.0)$ & $32(11.0)$ & \multirow{2}{*}{$<0.01$} \\
\hline Complete & $1,720(94.7)$ & $97(5.3)$ & \\
\hline
\end{tabular}




\begin{tabular}{|c|c|c|c|}
\hline \multirow[b]{2}{*}{ Variable } & \multicolumn{2}{|c|}{ Acceptance of JE immunization } & \multirow[b]{2}{*}{$\mathbf{p}$} \\
\hline & $\begin{array}{c}\text { Received } \\
\text { n (\%) }\end{array}$ & $\begin{array}{c}\text { Not received } \\
\text { n (\%) }\end{array}$ & \\
\hline \multicolumn{4}{|l|}{ Perception of susceptibility } \\
\hline Low & $597(93.3)$ & $43(6.7)$ & \multirow{2}{*}{0.45} \\
\hline High & $1,381(94.1)$ & $86(5.9)$ & \\
\hline \multicolumn{4}{|l|}{ Perception of severity } \\
\hline Low & $718(92.5)$ & $58(7.5)$ & \multirow{2}{*}{0.05} \\
\hline High & $1,260(94.7)$ & $71(5.3)$ & \\
\hline \multicolumn{4}{|l|}{ Perception of benefits } \\
\hline Low & $235(90.7)$ & $24(9.3)$ & \multirow{2}{*}{0.02} \\
\hline High & $1,742(94.3)$ & $105(5.7)$ & \\
\hline \multicolumn{4}{|l|}{ Perception of barriers } \\
\hline High & $377(91.5)$ & $35(8.5)$ & \multirow{2}{*}{0.03} \\
\hline Low & $1,601(94.5)$ & $94(5.5)$ & \\
\hline \multicolumn{4}{|c|}{ Mother's knowledge of JE and JE immunization } \\
\hline Low & $78(97.5)$ & $2(2.5)$ & \multirow{3}{*}{0.02} \\
\hline Fair & $1,585(93.2)$ & $116(6.8)$ & \\
\hline Good & $314(96.6)$ & $11(3.4)$ & \\
\hline \multicolumn{4}{|l|}{ Information sources } \\
\hline Not informed & $182(88.3)$ & $24(11.7)$ & \multirow{4}{*}{$<0.01$} \\
\hline Media only & $310(90.6)$ & $32(9.4)$ & \\
\hline Face to face only & $868(94.5)$ & $51(5.5)$ & \\
\hline Combination of media \& face to face & 618 (96.6) & $22(3.4)$ & \\
\hline
\end{tabular}

Table 5 Adjusted OR of independent variables on the acceptance of JE mass immunization

\begin{tabular}{|c|c|c|c|c|}
\hline \multirow[b]{2}{*}{ Variable } & \multirow[b]{2}{*}{ AOR } & \multicolumn{2}{|c|}{$95 \% \mathrm{Cl}$} & \multirow[b]{2}{*}{$\mathbf{p}$} \\
\hline & & Upper & Lower & \\
\hline \multicolumn{5}{|l|}{ Perception of severity } \\
\hline Low & Ref & & & \\
\hline High & 1.17 & 0.75 & 1.81 & 0.49 \\
\hline \multicolumn{5}{|l|}{ Perception of benefits } \\
\hline Low & Ref & & & \\
\hline High & 1.31 & 0.69 & 2.49 & 0.41 \\
\hline \multicolumn{5}{|l|}{ Perception of barriers } \\
\hline High & Ref & & & \\
\hline Low & 1.33 & 0.77 & 2.28 & 0.31 \\
\hline Knowledge of mother & & & & 0.08 \\
\hline Low & Ref & & & \\
\hline Fair & 0.29 & 0.07 & 1.24 & 0.10 \\
\hline Good & 0.50 & 0.10 & 2.42 & 0.39 \\
\hline Mother's level of education & & & & 0.06 \\
\hline No school & Ref & & & \\
\hline Elementary and junior high & 1.55 & 0.64 & 3.76 & 0.33 \\
\hline Senior high & 1.20 & 0.48 & 2.97 & 0.70 \\
\hline College or university & 0.83 & 0.32 & 2.18 & 0.70 \\
\hline
\end{tabular}




\begin{tabular}{|c|c|c|c|c|}
\hline \multirow[b]{2}{*}{ Variable } & \multirow[b]{2}{*}{ AOR } & \multicolumn{2}{|c|}{$95 \% \mathrm{Cl}$} & \multirow[b]{2}{*}{$\mathbf{p}$} \\
\hline & & Upper & Lower & \\
\hline \multicolumn{5}{|l|}{ District of residence } \\
\hline Denpasar City & Ref & & & \\
\hline Other district & 2.32 & 1.49 & 3.62 & $<0.01$ \\
\hline \multicolumn{5}{|l|}{ Age of child (years) } \\
\hline$\leq 5$ & Ref & & & \\
\hline$>5$ & 0.93 & 0.47 & 1.84 & 0.84 \\
\hline \multicolumn{5}{|l|}{ Sex of child } \\
\hline Male & Ref & & & \\
\hline Female & 1.68 & 1.15 & 2.46 & $<0.01$ \\
\hline \multicolumn{5}{|l|}{ Child education } \\
\hline No school & Ref & & & \\
\hline School & 2.43 & 1.23 & 4.79 & 0.01 \\
\hline \multicolumn{5}{|l|}{ Child immunization history } \\
\hline Complete & Ref & & & \\
\hline Incomplete & 2.22 & 1.42 & 3.49 & $<0.01$ \\
\hline \multicolumn{5}{|l|}{ Information sources } \\
\hline Not informed & Ref & & & \\
\hline Media only & 1.14 & 0.61 & 2.15 & 0.68 \\
\hline Face to face only & 2.11 & 1.21 & 3.70 & $<0.01$ \\
\hline Combination of media \& face to face & 3.95 & 2.01 & 7.77 & $<0.01$ \\
\hline
\end{tabular}

information only $(\mathrm{AOR}=2.11 ; 95 \% \mathrm{CI}$ : 1.21-3.70) and girls (AOR=1.68; 95\%CI: 1.15-2.46). While the variables that are not statistically related to the acceptance of JE mass immunization are perception of severity ( $\mathrm{AOR}=1.17$; 95\% CI: 0.75-1.81), perception of benefits (AOR=1.31; 95\%CI: 0.69-2.49), perception of barriers (AOR=1.33; 95\%CI: 0.772.28), information from media only ( $\mathrm{AOR}=1.14$; 95\%CI: 0.61-2.15), mothers with moderate knowledge $(\mathrm{AOR}=0.29 ; 95 \% \mathrm{CI}: 0.07-1.24)$, mothers with good knowledge (AOR=0.50; 95\%CI: 0.10 2.42), mothers with higher education $(\mathrm{AOR}=0.83$; 95\%CI: 0.32-2.18), mothers with senior high school education $(\mathrm{AOR}=1.20$; 95\% CI: 0.48-2.97), mothers with elementary and junior high school education $(\mathrm{AOR}=1.55$; 95\%CI: 0.64-3.76) and child age (AOR=0.93; 95\%CI: 0.47-1.84)

\section{DISCUSSION}

The proportion of children who received immunizations was $93.9 \%$ (95\%CI: 92.8-94.9), lower but not significantly compared to the JE SIA survey, which was $94.5 \%$ (95\%CI: 93.7-95.2). ${ }^{10}$ It was due to the number of unit analysis of immunization acceptance in this study was only $63 \%$, that is, the child of the respondent's mother, whereas if at the time of the JE SIA survey the respondent was not a mother were not included in our analysis.

Our study shows that information with a combination of media and face to face, children who go to school, live outside of Denpasar, have a complete basic immunization, face to face information only and girls are significantly more likely to increase the receipt of JE mass immunization. Information source is found as an important variable in the context of acceptance of JE mass immunization in Bali, where information with a combination of media (especially television) and face to face (especially health workers and cadres) has a greater role than just face-to-face, though both are significant. Information with the media alone was found to be related in the bivariate analysis but not related in multivariate analysis.

The concept of face-to-face with effective communication has been shown to be better with regard to receiving vaccines ${ }^{22}$ although other studies have found that face to face information has only a low to moderate effect on increasing the receipt of vaccination of children. ${ }^{23}$ Therefore, information in the form of advice/solicitation from officials may provide results that are better but must be combined with information through media, especially television, for maximum results. The 
fact that mothers who have girls (female children) significantly increases the acceptance of JE mass immunization cannot be explained in our study and further research needs to be done to explore the role of child value factors. ${ }^{24,25}$

Immunization acceptance is found to be higher in school children than among those not in school. This is likely because immunization is easier to do in schools where the primary school participation rate in the Province of Bali is $96.44 \%{ }^{26}$ Whereas children who are not in school must be immunized at the PHC, and there is a possibility that the child could not be brought to the PHC by parents or family for various reasons including busy or distance from their residence to the immunization post. These two reasons are also found in other studies related to uptake of immunization. . $^{1024,27}$ In our study the age of the child has a significant relationship with the acceptance of JE mass immunization in bivariate analysis, but no relationship was found in multivariate analysis. This is likely due to the more dominant contribution of being school children than the children's age.

Children with a complete history of basic immunization significantly increase the acceptance of JE mass immunization. This is likely related to the mothers' positive response to the immunization program. Previous studies also showed the important role of mothers in children's immunization..$^{18-20}$

The highest proportion of children who did not receive immunizations were found in Denpasar City, where Denpasar is the capital of the province of Bali with the highest proportion of migrant population. ${ }^{21}$ The proportion of migrants visiting the PHC may be smaller so that they are not present when given face-to-face information. The results of the JE SIA qualitative survey show the phenomenon of lower JE immunization coverage among migrant populations as compared to locals. ${ }^{10}$ Migration factors are also found in studies in other countries where immunization coverage tends to be lower among migrants than in the general population in Delhi, China, and Nigeria..$^{28-30}$ The mothers' preferences to seek immunization services in the private providers may also have an important role as reported in other studies. ${ }^{10,31}$

Higher knowledge of JE or JE immunization, perceptions of higher severity, higher benefits and fewer barriers significantly increased the proportion of acceptance in the bivariate analysis, but no significant relationship was found in the multivariate analysis. This is probably because the provision of information about JE is close to the time when immunization is given and most children are immunized at school. The relationship between the timing of information provision, knowledge and perceptions of mothers, however, remains unclear. The results of studies on perception are very dependent on the study setting, indicators used, conditions at the time of measurement, research outcomes and results tend to be different depending on the context of the study. ${ }^{30,32} \mathrm{HBM}$ also has weaknesses that are generally common in all models of social cognition, where respondents may be aware of the purpose of the interview so are motivated to provide answers that are not in accordance with their personal perceptions (socially acceptable answers). ${ }^{33}$ Other studies show that the relationship between parental knowledge and vaccination coverage tends to be non-existent, and often people receive vaccinations even though their knowledge is limited about it. ${ }^{32}$ JE post immunization campaign surveys in India found that the acceptance of vaccines by the community did not depend entirely on knowledge but also on effective/impact of campaigns carried out through mass media. ${ }^{34}$ On the other hand, the factor of trust in health care providers and culture might be more influential, so one of the recommendations from The Strategic Advisory Group of Experts (SAGE) is to measure the possibility of parents' doubts about vaccines, for example in the instance of a culture that does not allow children to be immunized. ${ }^{25,32}$

Our study did not find a significant relationship between maternal education and the acceptance of JE mass immunization in both bivariate and multivariate analyzes. Mother's education was also found to be unrelated to the acceptance of Measles Rubella mass immunization in Sukoharjo ${ }^{15}$ while other studies found the opposite. ${ }^{35-37}$

Our study cannot be used to infer causal relationships. Another limitation is that in the analysis there was duplicated maternal data from 1,284 mothers to 2,107 , whereas only 1,284 were analyzed to find difficulties in determining immunization acceptance for mothers who had more than one child where there were children who were immunized and some were not. The results of the bivariate analysis comparing the status of receiving JE immunization in mothers with one child (644) and duplicated mothers $(2,107)$ were found to be differences in perception of severity, perceived benefits, perceived barriers, maternal education and area of residence. However, in multivariate analysis, the differences only occur in the area of residence. This shows that potential biases due to duplication may occur but are not significant. In addition, there is the possibility of a recall bias about events that have occurred a long time ago, namely the provision of basic immunization to children, especially in children of higher age. 


\section{CONCLUSION}

Information delivered with a combination of media and face to face education, school children, children with complete basic immunization status, girls and only face to face information source had the highest contribution in JE mass immunization acceptance. Intensive information with the appropriate channels is needed during the immunization campaign period, especially by optimizing the role of health and non-health workers and using television as the education media. The afternoon working hours of the immunization services at PHC and the involvement of private clinics or hospitals during the campaign should be considered to minimize the number of children who are not immunized because their families cannot take children to the PHC during working hours in the morning.

\section{ACKNOWLEDGEMENTS}

Thanks to the Indonesian Ministry of Health, WHO for Indonesia, Udayana University, Bali Provincial Health Service and all those who contributed to this study.

\section{REFERENCES}

1. Indonesia Ministry of Health. Petunjuk teknis kampanye imunisasi Japanese ]enchepalitis (JE) [Technical guidelines of Japanese encephalitis (JE)]. Indonesia Ministry of Health. Jakarta: Indonesia Ministry of Health; 2017. $1-96 \mathrm{p}$.

2. Kari K, Liu W, Gautama K, Mammen MP Jr, Clemens JD, Nisalak A, et al. A hospital-based surveillance for Japanese encephalitis in Bali, Indonesia. BMC Medicine [Internet]. 2006;4(1):8

3. WHO. Media centre Japanese encephalitis [Internet]. 2015 [cited 2018 Oct 5]. p. 8-11. Available from: https://www.who.int/news-room/fact-sheets/detail/ japanese-encephalitis

4. SAGE. Background paper on Japanese encephalitis vaccines [Internet]. Geneva; 2014. Available from: https://www.who.int/immunization/sage/meetings/2014/ october/1_JE_Vaccine_Background_Paper.pdf

5. WHO. Japanese encephalitis vaccines [Internet]. WHO position paper. Elsevier; 2015. Available from: https:// linkinghub.elsevier.com/retrieve/pii/B9781455700905000094

6. Liu W, Clemens JD, Kari K, Xu ZY. Cost-effectiveness of Japanese encephalitis (JE) immunization in Bali, Indonesia. Vaccine. 2008;26:4456-4460.

7. Wirawan DN, Muliawan P. Laporan penelitian [Research report]. Vol. 1, Jurnal Manajemen. Denpasar; 2013.

8. Heffelfinger JD, Li X, Batmunkh $\mathrm{N}$, Grabovac $\mathrm{V}$, Diorditsa S, Liyanage JB, et al. Japanese encephalitis surveillance and immunization - Asia and Western Pacific Regions. MMWR Morbidity and Mortality Weekly Report [Internet]. 2017;66(22):579-583.

9. Tsai TF. New initiatives for the control of Japanese encephalitis by vaccination. Vaccine. 2002;18:1-25.

10. Sawitri AAS, Yuliyatni PCD. Coverage evaluation of Japanese encephalitis supplementary immunization activities (JE SIA) in Bali Island [Internet]. Denpasar; 2018. Available from: Unpublished report.

11. Institute of Medicine. New vaccine development establishing priorities. Vol. 2. Washington DC: National Academy Press; 1986. 1-432 p.
12. WHO. Manual for the Laboratory Diagnosis of Japanese Encephalitis Virus Infection [Internet]. 2007 [cited 2018 Oct 5]. p. 1-52. Available from: http://www.wpro.who.int/ immunization/documents/Manual_lab_diagnosis_JE.pdf

13. Valido EM, Laksanawati IS, Utarini A. Acceptability of the dengue vaccination among parents in urban poor communities of Quezon City, Philippines before and after vaccine suspension. BMC Research Notes [Internet]. 2018;11(1):661.

14. Brieger D, Edwards M, Mudgil P, Whitehall J. Knowledge, attitudes and opinions towards measles and the MMR vaccine across two NSW cohorts. Australian and New Zealand Journal of Public Health. 2017;41(6):641-646.

15. Prabandari GM, Musthofa SB, Kusumawati A. Beberapa faktor yang berhubungan dengan penerimaan ibu terhadap imunisasi measles rubella pada anak SD di Desa Gumpang, Kecamatan Kartasura, Kabupaten Sukoharjo [Factors associated with mothers' acceptance towards measles and rubella vaccination among elementary school children in Gumpang Village, Kartasura Subdistrict, Sukoharjo District]. Jurnal Kesehatan Masyarakat. 2018;6(4):573-581.

16. Turiho AK, Okello ES, et al. Perceptions of human papillomavirus vaccination of adolescent schoolgirls in western Uganda and their implications for acceptability of HPV vaccination: A qualitative study. BMC Research Notes. 2017;10(1):1-16.

17. Krawczyk A, Perez S, King L, Vivion M, Dubé E, Rosberger Z. Parents' decision-making about the human papillomavirus vaccine for their daughters: II. Qualitative results. Human Vaccines and Immunotherapeutics. 2015;11(2):330-6.

18. Berenson $\mathrm{AB}$, Laz TH, Rahman M. Effect of the decision-making process in the family on HPV vaccination rates among adolescents 9-17 years of age. Human Vaccines and Immunotherapeutics. 2014;10(7):1807-1811.

19. Tsuchiya Y, Shida N, Izumi S, Ogasawara M, Kakinuma W, Tsujiuchi T, et al. Factors associated with mothers not vaccinating their children against mumps in Japan. Public Health [Internet]. 2016;1-11.

20. Ahmed SM, Rahman TAA-E, Masoed ES. Mothers' awareness and knowledge of under five years children regarding immunization in Minia City, Egypt. Life Science Journal. 2013;10(4):1224-1232.

21. Indonesia Statistics Beureau. Penduduk Provinsi Bali menurut kabupaten/kota, jenis kelamin dan status migrasi seumur hidup hasil Sensus Penduduk 2010 [Internet] [Population of Bali Province by districts/city, gender dan lifelong migration, the results of The 2010 Population Census]. Denpasar; 2018 [cited 2019 Apr 11].p. 1. Available from: https://bali.bps.go.id/statictable/2018/02/15/37/ penduduk-provinsi-bali-menurut-kabupaten-kota-jenis-kelamin-dan-status-migrasi-seumur-hidup-hasil-sensus-penduduk-2010.html

22. Danchin M, Nolan T. A positive approach to parents with concerns about vaccination for the family physician. Australian Family Physician. 2014;43(10):690-694.

23. Kaufman J, Synnot A, Ryan R, Hill S, Horey D, Willis N, et al. Face-to-face interventions for informing or educating parents about early childhood vaccination. The Cochrane Database of Systematic Reviews [Internet]. 2013. 5:1-113.

24. Hilber AM, Bosch-Capblanch X, et al. Gender and Immunisation: Summary Report for SAGE, November 2010. 2010;(November 2010). Available from: http://www. who.int/immunization/sage/1_immunization_gender_ reports_without_graphics.pdf

25. WHO. Vaccine hesitancy survey questions related to SAGE vaccine hesitancy-examples of survey questions designed to assess determinants of vaccine hesitancy [Internet]. 2016 [cited 2019 Jun 4]. p. 1-8. Available from: https:// www.who.int/immunization/programmes_systems/ Survey_Questions_Hesitancy.pdf

26. Indonesia Statistics Beureau. Angka partisipasi sekolah berdasarkan provinsi 2003-2015 [Internet] [School participation rate by province]. Denpasar; 2018 [cited 2019 Aug 5].p. 1. Available from: bps.go.id 
27. Bali Province Health Office. Laporan monitoring kampanye Japanese encephalitis (JE) di Provinsi Bali tahun 2018 [The 2018 report on the monitoring of Japanese encephalitis campaign in Bali Province]. Denpasar; 2018.

28. Hu Y, Li Q, Chen E, Chen Y, Qi X. Determinants of childhood immunization uptake among socio-economically disadvantaged migrants in East China. International Journal of Environmental Research and Public Health. 2013;10:2845-2856.

29. Awoh $A B$, Plugge E. Immunisation coverage in ruralurban migrant children in low and middle-income countries (LMICs): a systematic review and meta-analysis. Journal of Epidemiology and Community Health [Internet]. 2016;70(3):305-11.

30. Skinner CS, Tiro J, Champion VL. The Health Belief Model. In: Glanz K, Rimer BK, Viswanath K, editors. Health behavior: theory, research, and practice. Fifth edition. San Fransisco: Jossey Bass; 2015. p. 98-118.

31. Tagbo B, Uleanya N, Nwokoye I, Eze JC. Mothers' knowledge, perception and practice of childhood immunization in Enugu. Nigerian Journal of Paediatrics [Internet]. 2012;39(3).

32. Jheeta M. Childhood vacination in Africa and Asia: the effects of parents' knowledge and attitudes. Bulletin of World Health Organization [Internet]. 2008; 6:419-419.
33. Abraham C, Sheeran P. The Health Belief Model. In: Conner $\mathrm{M}$, Norman P, editors. Predicting and changing health behaviour research and practice with Social Cognition Models. Third edition. London: Open University Press; 2015. p. 49-50.

34. Kumar D, Singh AJ. Response of various stakeholders towards newly introduced Japanese encephalitis vaccine in a North Indian State. Journal of Vaccines. 2014;2014:1-4.

35. Schülein S, Taylor KJ, Klug SJ. Factors influencing uptake of HPV vaccination among girls in Germany. BMC Public Health [Internet]. 2016;16(1):1-8.

36. Anello P, Cestari L, Baldovin T, Simonato L, Frasca G, Caranci N, et al. Socioeconomic factors influencing childhood vaccination in two northern Italian regions. Vaccine [Internet]. 2017;35(36):4673-80.

37. Ogboghodo E, Esene H, Okojie OH. Determinants of uptake of pentavalent vaccine in Benin City, Southern Nigeria. International Journal of Community Medicine and Public Health [Internet]. 2016;3(11):3195-201.

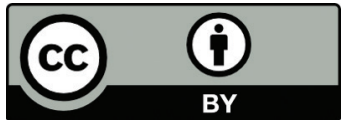

This work is licensed under a Creative Commons Attribution 